\title{
The Prospects or Myths of Mass Struggle to Uproot Capitalism and Implant a Socialist Order in Africa- A Review Article
}

\author{
John Olushola Magbadelo* \\ Director, Centre for African \& Asian Studies, Nigeria
}

Submission: May 05, 2020; Published: June 02, 2020

"Corresponding author: Dr. John Olushola Magbadelo, Director, Centre for African \& Asian Studies, Abuja, Nigeria

Keywords: Elicit intellectual; Socialist; Peculiar structure; Capital-intensive nature; Mineral resources; Imperialism; Neoliberalism

Review

Lee Wengraf, Extracting Profit: Imperialism, Neoliberalism, and the New Scramble for Africa, Chicago, Haymarket Books, 2018. Vii $+339 P P$.

The current developmental challenges in Africa have continued to elicit intellectual concerns of curious scholars across the world on how the situation of the continent would change. It is indeed remarkable that radical scholars of the Marxist strand of scholarship are undeterred in their agitations for Marxist revolution in Africa. Lee Wengraf's book is one of such radical renditions on the imperative of changing the subsisting exploitative relationship between the developed economies of the world and Africa. The book is an elaboration of the systematic radical scholarship of the early 1970s and 1980s on Africa's dilemma in the world's capitalist system. This book has a peculiar structure that makes its reading an interesting and worthwhile venture. Beginning with chapter one which provides a bird's eye view of the book's contents, all through the eight chapters of the book, the theoretical import of Africa's current predicament is situated within the context of Africa's historical contact with the colonial powers and the abiding consequences of the improperly executed political independence of the colonized territories of Africa. This book affirms that the exploitation of Africa from the period of itssordid and unpleasant contact with the West has continued into the recent neoliberal era. Neoliberalism is conceptualized by our author as the dismantling of barriers to corporate globalization and accumulation evident in the imposition of free trade agreements, austerity, and attacks on unions (P. 3).
This book has two broad parts. The first part highlights the legacies of colonialism including the poor or limited capacity of the emergent ruling classes in Africa, the uncritical acceptance of neoliberalism with all its socioeconomic and political implications for Africa's development. The author in this part of the book observes that the often publicized claim of 'Africa rising 'does not take into consideration the contradictions in the nature of the economy which would inevitably be explored as African nations approach a new period of downturn and crisis (p. 120).

In part two of the book, the processes that led to the new scramble for Africa and in particular, the rising interest of the West and China in the oil and natural resources of the continent are chronicled. The author notes the capital-intensive nature of the series of investment in the extraction of oil and mineral resources of Africa. She analyzes the features and consequences of the new scramble for Africa's resources, and observes the weak regulatory environment of foreign investment in Africa, which is an apparent indictment of the governing elites or ruling classes in Africa. The attendant crises of the scramble for Africa's resources are lucidly examined against the backdrop of unfulfilled expectations of the host communities which had unwittingly anticipated that the huge foreign investment outfits in their domains would have transformational impacts on them.

Utilizing Nigeria, South Africa, Angola as case studies of the impacts of foreign investment in Africa's oil and mineral resources, the author affirms that the nature of those investments is explanatory of the series of conflicts and instabilities in the 
communities hosting those oil prospecting and exploratory companies, noting that the conversation on whether or not Africa's possession of abundant oil and mineral resources is a curse or blessing springs from the palpable paradox in which the existential realities of the host communities of foreign investments are the exact opposite of the benefits accruable to the foreign investors. Specifically, chapter six of the book which is titled: 'Resource curse or Resource wars 'presents an explicit survey of the situations across the continent. The lack of transparency, proneness of the processes of the investment in the oil and mineral sectors in Nigeria, Angola, Democratic Republic of Congo (DRC), etc. to corruption, as well as the absence of result-oriented reforms in the regulatory framework for corporate extraction are considered as some of the reasons for the lackluster performance of extractive industries in Africa. She, therefore, affirms that "African societies are not cursed by natural resources, but rather by and wars produced by the drive for extraction and profits" (p. 190).

The seventh chapter which exposes the desperation of the US to retain its sphere of influence in Africa, evident in the pursuit of the militarization project tagged African Command (AFRICOM), which its proponent portrays as being in the best interest of Africa, but which our author forthrightly observes was a grand strategy of the US' ruling class to protect America's interest in Africa - an interest that the growing relationship between Africa and China could threaten (P.195). This new contest for Africa is described as 'cold war imperialism in Africa' (P.196). The humanitarian intervention in African situations by the West, especially the US, is portrayed by the author as a manifestation of' the geopolitics of imperial energy security' which the US has been utilizing to sharpen its Foreign Policy, particularly since the collapse of the Soviet Union- a development which enabled the US military power to become the dominant force in the world affairs.

The eighth chapter on 'Class Struggle and Permanent Revolution' highlights the series of protest and resistance movements organized by the working class against the policies of the ruling classes in Africa. These included strikes against wage cuts, anti-poverty activism, mobilizations for AIDS treatment, and struggles against the privatization of water and electricity, as well as movement for debt relief. The author admits that many of those struggles laid the basis for alliances and longerterm battles over basic needs and human rights for workers and the poor today (P. 234). The extensive theoretical debate on the analytical utility of Trotsky's concept of 'permanent revolution' would appear unhelpful (pp. 238- 241). There is a glorification of workers strikes in Africa in periods between the 1990s and 2015, especially in Nigeria, Burkina Faso, and South Africa, which the author's celebratory tone describes as 'the revolutionary wave'(P. 243). In the absence of an operational definition of the concept of 'revolution', the analysis of our author falls short of the requirements for scientific theorizing. There is the need for indepth analysis of the workers union and their strategic operations in Africa in order to bring clarity to the modes of operation of this critical group in the socio-economic formations of African societies. African working classes in contemporary times are bereft of ideological objective which ought to drive their agitations. Workers in Africa have limited objective; they are not agitating for any qualitative change in governmental systems nor are they demanding for their rights on the strength of any ideologicallyinspired perspectives on public policies. Workers struggles have been limited to salary increase, and at times welfare reliefs. In few instances when workers unions in Nigeria ventured into policy issues, they were spontaneously supported by the masses because the workers left their comfort zone by demonstrating interest in economy-wide issues which affect workers and non-workers alike.

The palpable lack or absence of ideological pedagogy for conscientizing the working classes and indeed the masses in Africa is responsible for the less assertive and less ambitious objective of the scattered and isolated working class outbursts, which cannot in any way originate ideologically-propelled revolution of the type that the Marxists anticipate [1].

The narrative of the book gives the impression of Africa's helplessness to reverse its unfortunate relations in the global capitalist order. The responsibility for Africa's extant economic and political underdevelopment is placed at the doorstep of the misfortune of its contact with the West and the repercussions on Africa of the exploitative relations between the two since that period. The question to ask is: how can the colonial past still hold Africa hostage despite its political independence? In admitting that western multinationals and African elites have accumulated vast profits from their investments in Africa's abundant natural resources, our author avers that the scramble for Africa is a project of African elites in connivance with their counterparts from the West- a development she describes as 'a scramble for Africa's natural resources' and which she observes, is not a new reality (P. 4).

Placing the contest between the West and China for Africa's resources in perspective, this book posits that whilst the boom in China's economy spurred its drive for new resources of energy and markets, the West is fighting to retain her spheres of influence on the strength of historicity lacking objective economic rationality for their claim to Africa's abundant resources. The contest between the US and China over Africa is portrayed as one which has turned the continent into a competitive ground for both countries pursuit of their separate and disparate interests which have no bearing on Africa's long term survival. America's African Military Command known as AFRICOM was conceived as the initiative to sustain US' hold on Africa. It is significant that our author describes this development as international militarism in Africa which could instigate economic crises in which the capitalists increasingly turn to the armed power of their States to secure access to markets, territories, and control of national resources especially, oil (P. 6).

In critiquing the myths and realities of Africa's underdevelopment, an attempt was made to present a perspective 
on Africa's reality. However, certain issues were left unanswered. In debunking the position that Africa's poverty is an inevitable, inescapable feature of African States themselves, our author refuses to explain if there was anything making it impossible for postcolonial African State to restructure the subsisting inherited structures of underdevelopment in Africa (p. 8). In responding to the claim that: Any debt owed by the West has been paid in full and must be put behind us, our author asserts that 'African poverty is rooted in the global relations of postcolonial states burdened by the legacy of colonialism and neoliberal policy- policies embraced today by the world's ruling classes, including African ones. But, our author unwittingly plunges herself into a blame game in an attempt to redress what she calls 'blame the victim foreign policy' (p. 8). The related question on whether Africa needs reparation was not answered by our author. In her critique of the fallacious and contentious assertions of some western scholars (including Paul Collier, Jeffrey Sachs and Joseph Stieglitz) that the possession of abundant natural resources by developing countries have continued to turn out to be 'resource-curse, our author opines that such views are 'ahistorical explanations which overlook the structural and the distorting impact of the extractive industries and capitalist global relations (p. 9). But, the issue is not the ahistorical nature of the assertions of those western scholars; rather, it is their deliberate refusal to understand that there is nothing inherently evil or bad with the natural resources which some African countries possess in abundance. Shifting the blame for the reckless and imprudent management of the abundant natural resources in Africa away from the leadership of those countries and placing the blame on the resources is not only escapist and diversionary, it is mischievous. The argument that the abundant natural resources in Africa constitute an evil and that they amount to a curse is the same as saying that the natural resources ought to utilize themselves for development regardless of the roles expected of African leadership. The resource- curse thesis is an exculpatory justification of the problem of leadership and governance in resource-rich African countries. The dearth of visionary leadership in Africa is the main reason why the natural resources which are better harnessed and utilized for the development of some other countries, are criminally mismanaged in Africa for the benefit of African bureaucrats, business executives and their collaborators from the West, Asia and recently, China.

In debunking another myth that African nations are ungovernable, dominated by failed states and trapped by an unrelenting propensity for violence, our author blamed international media for biased reportage on Africa. She notes that the misrepresentation of Africa was without regard to context which gives the erroneous impression that the continent 'is given to fighting over no discernible issue' (p.9). The point ought to have been made by our author that, in actuality African nations are not ungovernable, but they have not really been governed well since their attainment of political independence. African masses are not in any way opposed to good governance which has seemingly over the years been elusive in the continent's political landscape.
In respect of the myth that ordinary Africans are merely passive victims of authoritarian African rulers or fueled by the conflicts of age- old ethnic divides, our author observes that 'such myths of African rulers and citizens as rooted in primordial violence create a dangerous justification in an imperial context'. She therefore opines that: 'ostensibly only international (Western) intervention - of the watchdog, humanitarian or direct military kind- can save the continent from inevitable bloodshed' (p. 9). Our author's resort to sarcasm on a very serious matter bordering on the political stability and social order or otherwise in Africa is confusing. It is not right to present ethnic conflict in Africa as a 'primordial violence'; conflict of any kind can erupt at any given time in history. What is important is to establish the causative factors that predispose citizens to violent political behavior whether in a contemporary times or in prehistoric period. Ethnic rivalries are a manifestation of poor governance in African States. And until the governance issues are resolved, there is no international or Western intervention that can on a permanent basis guarantee ethnic amity where the socio-political fabrics of the States had been fractured by bad governance.

The last myth which our author interrogates says mass unemployment and crisis make resistance in Africa futile- a myth she observes has made some radical scholars, especially, the critics of corporate globalization and imperial intervention in Africa to agree that those sordid existential realities have rendered political organization and sustained resistance impossible. Our author, however, after reviewing all the arguments that lend credence to this myth, avers that 'the stubborn reality of long-standing traditions of struggle and resistance among ordinary Africans challenges assumptions of the futility of change' (pp. 9- 10). Although, our author did not specify any historical reference points to validate her claim of the existence of the traditions of struggle and resistance in Africa, there is some theoretical confusion in the whole analyses of the kind of struggle and resistance that our author is contemplating. Utilizing Marxism to explicate the probability of class struggle and resistance against an unwanted socio economic and political order in Africa, would reveal that the higher the degree and intensity of exploitation of the African masses by the ruling classes which culminates in a heightened sense of realization of deprivation on the part of the masses, the higher the prospects of struggle and resistance by the masses. What has been averting or dousing the flames of revolt, struggle and agitation by African masses is the dubious utilization of the principles of economic and political seduction by the ruling classes through bribery, tokenism and strategic cooption of the principal leaders of the radical elements and critics in African states. Where these efforts to mollify the masses fail, African ruling classes have often resorted to brute force to quench the smoldering agitation, struggles and resistance. However, the objective conditions of African socio-economic formations are currently not supportive of any long- drawn mass struggle or resistance against established order in most African States. 
On the contrary, our author expresses great optimism about the prospects of mass struggle from below in countries such as Burkina Faso, Nigeria, South Africa, Ivory Coast, and Zimbabwe, noting 'the power of working classes on the continent', and affirms that 'the evidence conclusively puts to rest the notion of a planet of slums in Africa, where ordinary people lack agency to bring about social change' (p. 251). Elsewhere, she argues that 'the working classes in Africa hold the potential to build alliances with wider sections of society and thus lead in those struggles for change facing all of the oppressed on the continent, from the urban slums to the rural poor' (p. 255). From our author's expressed expectations, it is clear that they are not based on any rigorous scientific analysis of the objective conditions of working class unions in Africa. It is not helpful in any way to lump working classes in Africa together as a case study of what the future of working class struggle for change in Africa would look like. The major problem of working classes in Africa is how they can play significant role in the formulation of policies that would positively impact on their existential realities. The other problem is the lack of ideological clarity and commitment on the part of the working classes in Africa. This leads to the question of how workers parties can be organized as critical ideology-propelling machines for the transformation of Africa. Workers parties in Africa ought to be actively in season before, during and after electoral contest; they should not function merely as vehicles for electoral power alone but for the conscientization of the masses and the empowerment of the working classes in Africa.

In her concluding remarks, our author recommends that: ' $A$ globally interconnected system of capitalism can only be replaced by a struggle from below, one likened to interconnected systems across workplaces, communities, and nations. For the left, the struggle to uproot capitalism in Africa can only advance the fight for its alternative everywhere' (p. 256). It is rather ambitious to assume that because workplaces ,communities and nations are interconnected, the struggle from below against capitalism would lead to the replacement of capitalism with a socialist order. The interconnection of the subjects of global capitalism has long been established but there is no unanimity of objectives among the working classes of the world. It seems rather more difficult in contemporary times to think of upturning at once the global capitalist order. Rather, there could be a global ideological solidarity for the country- to- country implantation of socialist order through the ideologically-propelled working class struggle for change, which also in this present and time is an uphill task.

Overall, the book is an interesting piece on the exploitative mechanics of global capitalism in contemporary times, using the ever-increasing propensity for capital accumulation from the oil fields and rich mineral deposits in Africa by the countries of the West, especially the US as the new age means of perpetuating Africa's underdevelopment. The growing relevance of Africa to the geostrategic policies of the US and China is brilliantly analyzed with empirically verifiable data in the book. Aside from chronicling the deleterious consequences of Africa's disadvantaged status in the global capitalist system, strategies for Africa's transformation through organized working class struggles and resistance are advanced. No doubt, this book lends credence to the pioneering works of such radical scholars as Andre Gunder Frank, Walter Rodney,Samir Amin, Claude Ake and a host of others, thereby expanding the frontiers of radical scholarship on Africa's dilemma in the global capitalist order.

\section{References}

1. (1968) This analysis gained insight from the book written by Paulo Freire, Pedagogy of the Oppressed.

\begin{tabular}{|l|}
\hline \multicolumn{1}{|c|}{ Your next submission with Juniper Publishers } \\
will reach you the below assets \\
- Quality Editorial service \\
- Swift Peer Review \\
- Reprints availability \\
- E-prints Service \\
- Manuscript Podcast for convenient understanding \\
- Global attainment for your research \\
- Manuscript accessibility in different formats \\
( Pdf, E-pub, Full Text, Audio) \\
- Unceasing customer service \\
Track the below URL for one-step submission \\
https://juniperpublishers.com/online-submission.php
\end{tabular}

